ОСОБЛИВОСТІ ДОКУМЕНТУВАННЯ BИTРАТ ОРГАНІЧНОГО СІЛЬСЬКОГОСПОДАРСЬКОГО ВИРОБНИЦТВА

\section{ІЩЕНКО Я.П., кандидат економічних наук, доцент кафедри обліку та оподаткування в галузях економіки}

КОВАЛЬ Н.I., кандидат економічних наук, доцент кафедри обліку та оподаткування в галузях економіки, Вінницький національний аграрний університет (м. Вінниця)

Iз досліджень, проведених науковцяли, зроблено висновок, щзо сьогодні спостерігається брак інформаиії про органічний сегмент виробниитва. Це обумовлено відсутністю комплексної методики обліку органічного сільськогосподарського виробництва, розробку якої варто розпочати з документального забезпечення обліку витрат та виходу органічної продукції.

Публікація присвячена дослідженню стану первинного обліку витрат на виробництво органічної продукиії сільськогосподарського виробництва та розробиі науковообтрунтованих рекомендацій для аграрних підприємств щодо документального забезпечення обліку витрат виробниитва органічної продукиії рослинництва.

У результаті дослідження виокремлено напрями використання інформації первинних документів, якими оформляються витрати на виробництво органічної продукції. Окреслено функиї первинних документів в управлінні витратами виробництва продукції органічного походження. Обгрунтовано необхідність створення спеціалізованих форм первинного обліку витрат насіння, посадкового матеріалу, засобів захисту рослин, добрив, як таких, щяо потребують особливого контролю у процесі виробництва органічної продукиії. Окреслено організачійно-технологічні особливості та специфіку контролю під час перехідного періоду, в умовах «чистого» органічного виробництва та в умовах паралельного виробництва органічної $і$ неорганічної продукиії, які слід враховувати при документуванні витрат. Запропоновано загальні підходи до документування витрат та розроблено форму Акту про використання речовин (інгредієнтів, компонентів), які дозволяється використовувати у прочесі органічного виробництва, та які дозволені до використання у гранично допустимих кількостях. Розроблені пропозииіі дозволять забезпечити контроль за дотриманням законодавства у сфері органічного виробництва, реалізувати контрольну та інформаційну функції первинних документів із обліку витрат на виробництво продукції рослинництва органічного походження.

Ключові слова: документування, первинні документи, витрати виробництва, органічне виробництво, органічна продукція, реквізити.

Табл.: 1. Рис.: 4. Літ.: 16. 


\title{
FEATURES OF DOCUMENTATION OF EXPENSES OF ORGANIC AGRICULTURAL PRODUCTION
}

\author{
ISHCHENKO Yana, \\ Candidate of Economic Sciences, Associate Professor \\ of the Department of Account and Taxation \\ in the Fields of the Economy \\ KOVAL Natalia, \\ Candidate of Economic Sciences, Associate Professor \\ of the Department of Account and Taxation \\ in the Fields of the Economy, \\ Vinnytsia National Agrarian University

From the research conducted by scientists, we can conclude that today there is a lack of information related to the organic segment of production.Thisis due to the lack of a comprehensive methodology of accounting organic production, the development of which should begin with the documentation of cost accounting and yield of organic products.

The publication is devoted to the study of the state of primary accounting of the costs in organic agricultural production and the development of scientifically sound recommendations to agricultural enterprisesregardingthe documentation of accounting for the costs oforganic crop productsproduction.

As a result of the research, the directions of using the information of primary documents, which formalize the costs of organic production, are grouped. The functions of primary documents in the management of organic production are outlined. The necessity of creation of the specialized formsforprimary accounting of seeds expenses, planting material, protection plants means, fertilizers as those which need special control in the course of production of organic products is substantiated.The organizational and technological features and specifics of the control during the transition period, in terms of «pure» organic production and in terms of parallel production of organic and inorganic products, which should beconsideredwhen documenting costs, are highlighted.The general approaches to documentation of expenses are offered and the form of the Act on use of substances (ingredients, components) which is allowed to be usedduringorganic production and which are allowed to use in maximumadmissiblequantities is developed.The developed proposals will allow to providecontrol over observance of the legislation in the field of organic production, to realize control and information functionsforprimary documentsofaccounting costsinorganic crop production.

Key words: documentation, primary documents, production costs, organic production, organic products, details.

Tabl.: 1. Fig.: 4. Ref.: 16.

\section{ОСОБЕННОСТИ ДОКУМЕНТИРОВАНИЯ РАСХОДОВ ОРГАНИЧЕСКОГО СЕЛЬСКОХОЗЯЙСТВЕННОГО ПРОИЗВОДСТВА}

ИЩЕНКО Я.П., кандидат экономических наук, доцент кафедры учета и налогообложения в отраслях экономики 
КОВАЛЬ Н.И., кандидат экономических наук, доцент кафедры учета и

налогообложсения в отраслях экономики, Винницкий национальный аграрный университет (2. Винница)

Как свидетельствуют научные исследования, сегодня наблюдается нехватка информации об органическом сегменте производства. Это обусловлено, на наш взгляд, отсутствием комплексной методики учета органического производства, разработку которой следует начать с документального обеспечения учета затрат $u$ выхода органической продукиии.

Публикачия посвящена исследованию состояния первичного учета затрат органического сельскохозяйственного производства и разработке научно обоснованных рекомендаций по документированию издержек производства органической продукиии растениеводства.

В результате исследования сгруппированы направления использования информации первичных документов, которыми оформляются расходы органического производства. Определень функиии первичных документов в управлении органическим производством. Обоснована необходимость создания специализированных форм первичного учета затрат семян, посадочного материала, средств защиты растений, удобрений, как требующих особого контроля в процессе производства органической продукции. Определень организационно-технологические особенности и специффика контроля во время переходного периода, в условиях «чистого» органического производства и в условиях параллельного производства органической и неорганической продукции, которые следует учитывать при документировании расходов. Предложены общие подходы к документированию расходов и разработана форма Акта об использовании веществ (ингредиентов, компонентов), которую разрешается использовать в прочессе органического производства и разрешенных $\kappa$ использованию в предельно допустимых количествах. Разработанные предложения позволят обеспечить контроль соблюдения законодательства в сфере органического производства, реализовать контрольную и информационную функции первичных документов по учету затрат органического растениеводства.

Ключевые слова: документирование, первичные документы, издержки производства, органическое производство, органическая продукция, реквизиты.

Табл.: 1. Рис.: 4. Лит.: 16.

Постановка проблеми. Пріоритетними шляхами досягнення стратегічних цілей держави щодо розвитку агропромислового сектору, визначених Національною економічною стратегію на період до 2030 року, що затверджена Постановою Кабінету Міністрів України № 179 від 3 березня 2021 року, є:

- виконання програм із підтримки виробників органічної продукції та здійснення заходів, спрямованих на підвищення рівня обізнаності виробників щодо переваг ведення органічного виробництва;

- розроблення програм фінансової та дорадчої підтримки виробників органічної продукції;

- залучення більшої кількості виробників до ведення органічного виробництва шляхом удосконалення державного регулювання в зазначеній 


\section{EФM \\ http://efm.vsau.org/}

cфepi;

- забезпечення розвитку сталого виробництва, де завданням для уряду є заохочення захисту навколишнього природного середовища i тварин, поширення застосування методів органічного виробництва і використання біотехнологій, «кліматично розумного» сільського та лісового господарства зі скороченням викидів парникових газів та адаптацією до змін клімату, сталого управління природними ресурсами та збереження i примноження біорізноманіття [1].

Розвиток органічного виробництва в Україні та світі є відповіддю на зростаючий попит населення $\mathrm{y}$ якісних, органічно-чистих продуктах харчування. Завдяки сприятливим грунтово-кліматичним умовам та популяризації органічної продукції за останні десять років спостерігається позитивний тренд $\mathrm{y}$ кількості сертифікованих операторів органічного виробництва, площах сільськогосподарських угідь із органічним статусом, асортименті органічної продукції; розширюються внутрішній та зовнішні ринки збуту української органічної продукції; формується правова база регулювання сертифікації, виробництва, маркування та обігу такої продукції.

Органічне виробництво у такій аграрній країні, як Україна, є одним із ключових факторів у вирішенні екологічних, економічних та соціальних проблем. Відтак, зростає коло осіб, зацікавлених в отриманні інформації про стан розвитку органічного виробництва, його витрати, собівартість органічної продукції тощо. Основою i підгрунтям інформаційного забезпечення управління $є$ первинний облік. Від первинного відображення (документування) операцій залежить подальше групування, узагальнення та якість інформації, яка використовуватиметься для забезпечення потреб і запитів користувачів.

Аналіз останніх досліджень і публікацій. Зважаючи на стратегічне значення для України сільського господарства загалом i органічного виробництва зокрема, вирішення проблем відображення в обліку виробництва органічної продукції сьогодні є однією із найбільш актуальних тем досліджень науковців-аграріїв. Проблеми організації екологічно-орієнтованої діяльності суб'єктів аграрного підприємництва та органічного сільськогосподарського виробництва є об'єктом наукових досліджень провідних вітчизняних науковців, зокрема, науковців Вінницького національного аграрного університету. Серед них: Г.М. Калетнік [2], І.В. Гончарук [3], С.Я. Ковальчук [4] та інші. Організації та методиці обліку виробництва органічної продукції присвячені дослідження О.А. Подолянчук [5; 6], Ю.С. Цаль-Цалка [7] та ін.

Проте, дослідження вчених iз означеної проблематики мають розрізнений, несистемний характер. Як слушно зазначають І.Г. Кириленко та Є.В. Милованов, вітчизняний органічний рух, як ніколи, потребує від наукової спільноти підвищення рівня залучення науковців до важливих питань наукового обгрунтування становлення органічного сектору в сучасних умовах розвитку аграрної галузі національної економіки [8, с. 37-38].

Наразі, уваги потребує розробка системи інформаційного забезпечення 


\section{EФM \\ http://efm.vsau.org/}

всіх рівнів управління органічним виробництвом. Нестача інформації про органічний сегмент виробництва призводить до гальмування надходження інвестицій та, відповідно, до гальмування його розвитку. Формування комплексної методики обліку витрат на виробництво органічної продукції варто розпочати $з$ документального забезпечення обліку витрат та виходу органічної продукції рослинництва.

Формулювання цілей статті. Метою статті $\epsilon$ дослідження стану первинного обліку витрат органічного сільськогосподарського виробництва та розробка науково-обгрунтованих рекомендацій аграрним підприємствам щодо документального забезпечення обліку витрат виробництва органічної продукції рослинництва.

Виклад основного матеріалу дослідження. Органічне сільськогосподарське виробництво в Україні є одним із пріоритетних напрямів розвитку аграрного сектору економіки, згідно 3 прийнятою Національною економічною стратегії на період до 2030 року (рис. 1) [1].

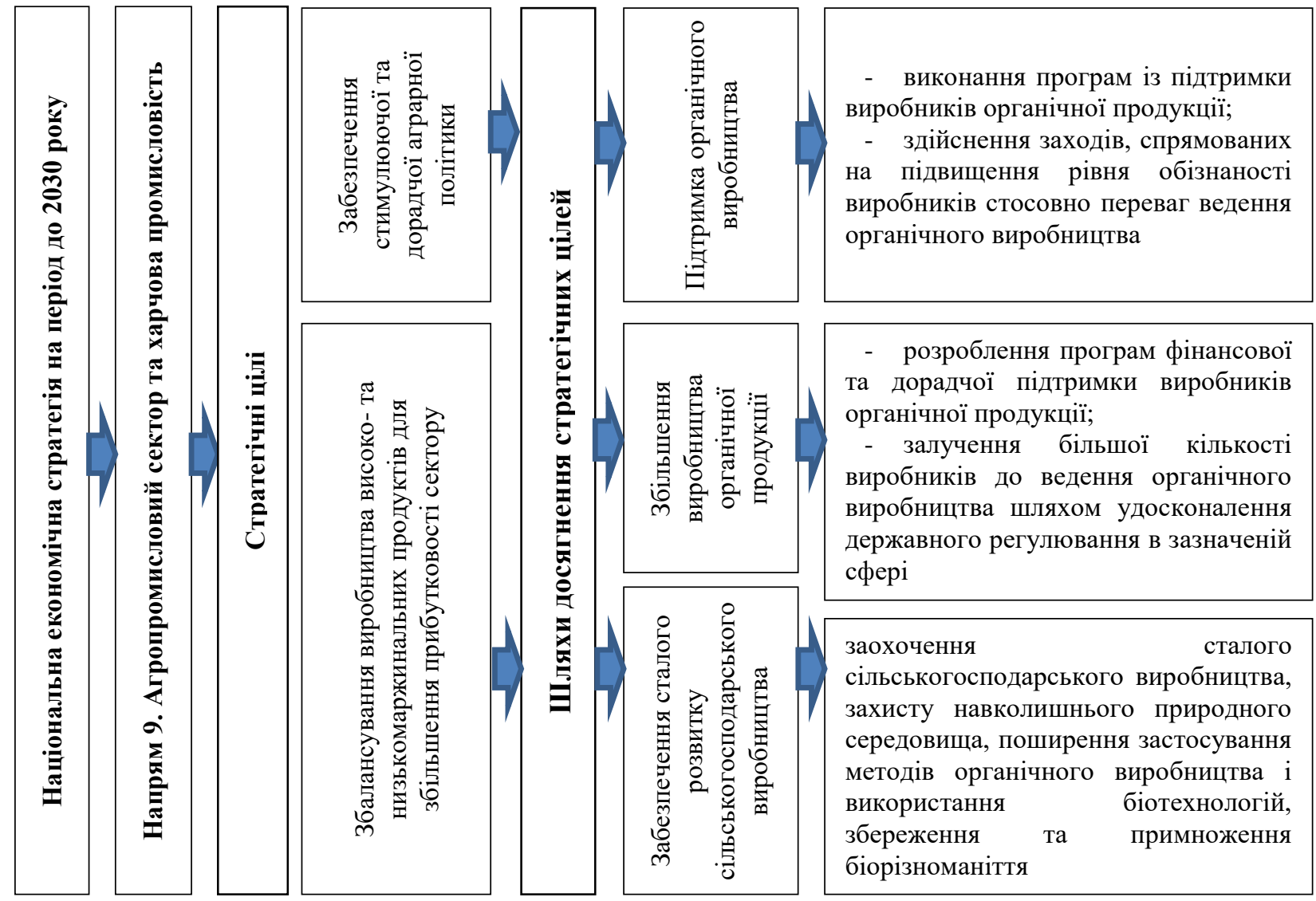

Рис. 1. Органічне сільськогосподарське виробництво України в

Національній економічній стратегії на період до 2030 року

Джерело: сформовано авторами на основі [1]

Розвиток органічного виробництва в Україні характеризується досить високими темпами (табл. 1) [11].

Серед цільових індикаторів досягнення стратегічних цілей розвитку 
агропромислового сектору виокремлено збільшення площі земель із органічним статусом до не менш, як 3\% загальної площі сільськогосподарських угідь (тобто до 1,3 млн га) та збільшення експорту органічної продукції до 1 млрд доларів США до 2030 року [1].

Таблиия 1

Динаміка розвитку органічного виробництва в Україні, 2015-2019 pp.

\begin{tabular}{|c|c|c|c|c|c|c|}
\hline \multirow{2}{*}{ Показники } & \multicolumn{5}{|c|}{ Роки } & 2019 р. до \\
\hline & 2015 & 2016 & 2017 & 2018 & 2019 & 2015 p., \% \\
\hline $\begin{array}{ll}\text { Кількість операторів } & \text { органічного } \\
\text { виробництва, од. } & \end{array}$ & 210 & 360 & 375 & 510 & 617 & 294 \\
\hline $\begin{array}{l}\text { Загальна площа сільськогосподарських } \\
\text { земель i3 органічним статусом та } \\
\text { перехідного періоду, тис. га } \\
\end{array}$ & 410,55 & 411,20 & 420,00 & 429,10 & 467,98 & 114 \\
\hline $\begin{array}{l}\text { Обсяги внутрішнього споживчого ринку } \\
\text { органічних продуктів, млн євро }\end{array}$ & 17,5 & 21,2 & 29,4 & 33,0 & 36,0 & 206 \\
\hline
\end{tabular}

Джерело: сформовано авторами на основі [11]

Однією із передумов досягнення поставлених цілей щодо розвитку органічного виробництва та належного його функціонування $\epsilon$ ефективне забезпечення інформаційних потреб стейкхолдерів, основою якого $є$ первинний облік всіх етапів органічного виробництва. Первинне спостереження є єдиною базою для формування інформаційних потоків управлінської, фінансової, статистичної та податкової звітності, що забезпечується суцільним та безперервним документуванням господарських операцій.

Згідно 3 Положенням про документальне забезпечення записів у бухгалтерському обліку, первинні документи - це документи, створені у письмовій або електронній формі, які містять відомості про господарські операції, і $є$ підставою для подальшого їх обліку. Обов'язковими реквізитами первинних документів $\epsilon$ найменування підприємства, установи, від імені яких складений документ, назва документа (форми), дата складання, зміст та обсяг господарської операції, одиниця виміру господарської операції (у натуральному та/або вартісному виразі), посади і прізвища осіб, відповідальних за здійснення господарської операції та правильність їі оформлення, особистий підпис або інші дані, що дають змогу ідентифікувати особу, яка брала участь у здійсненні господарської операції [12].

Враховуючи організаційно-технологічні та правові особливості органічного виробництва, що досліджено та висвітлено нами у попередніх публікаціях $[9,10]$, об'єктивно виникає необхідність отримання та групування інформації за виокремленими об'єктами обліку в розрізі витрат виробництва органічної продукції, витрат перехідного періоду та витрат виробництва неорганічної продукції.

Первинні документи складаються на бланках типових і спеціалізованих форм. Проте, передбачено, що документування господарських операцій може здійснюватися із використанням самостійно виготовлених бланків, які повинні містити обов'язкові реквізити. Відсутність розроблених типових документів із обліку витрат та виходу органічної продукції обумовлює необхідність 


\section{EФМ \\ http://efm.vsau.org/}

самостійного формування пакета первинних документів суб'єктами господарювання. При цьому повинні бути враховані стандарти органічного виробництва, дотримані вимоги чинного законодавства щодо виробництва, обігу та маркування органічної продукції, технологія виробництва продукції.

При моделюванні бізнес-процесів органічного виробництва та формуванні їх регламентів варто враховувати напрями використання інформації про витрати. Стосовно облікового забезпечення всіх рівнів управління, первинні документи про витрати на виробництво органічної продукції повинні містити інформацію за наступними напрямами подальшого використання:

- оперативного аналізу, внутрішнього контролю і управління;

- зовнішнього контролю (державного контролю у сфері органічного виробництва, обігу та маркування органічної продукції за діяльністю операторів, контролю органів сертифікації, контролю покупців тощо);

- формування інформації для цілей фінансової звітності за національними та міжнародними стандартами;

- формування інформації для податкової та статистичної звітності.

Тому кожен документ має бути детально продуманий та змодельований. У комплексі з визначеним переліком документів необхідно сформувати змістовну частину кожного документа, що досягається шляхом визначення необхідної інформації для забезпечення усіх напрямів іiі використання. За умови такого комплексного підходу, первинний документ виконуватиме контрольну та інформаційну функції (рис. 2).

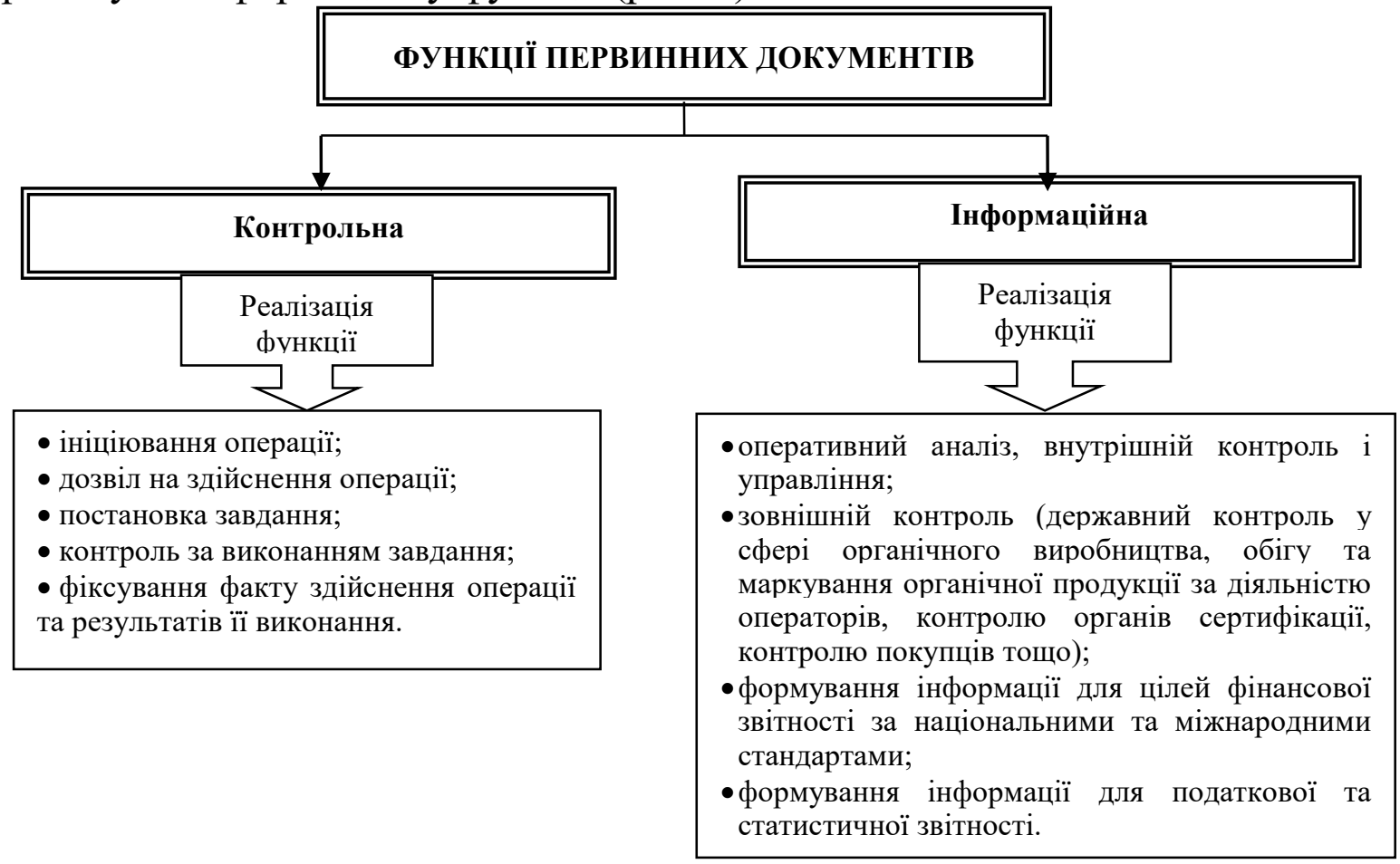

Рис. 2. Функції первинних документів в управлінні витратами виробництва органічної продукції

Джерело: власна розробка авторів 
Реалізація функції внутрішнього контролю забезпечується шляхом ініціювання операції, іiі дозволу, постановки завдання, контролю за його виконанням і фіксування факту здійснення операції та результатів виконання завдання. Функції зовнішнього контролю у сфері органічного виробництва покладено на органи сертифікації (під час процедури сертифікації та інспектування виробництва) та на Державну службу України 3 питань безпечності харчових продуктів та захисту споживачів (Держпродспоживслужбу), до повноважень якої належить здійснення державного контролю (нагляду) за дотриманням суб'єктами ринку органічної продукції законодавства у сфері органічного виробництва, обігу та маркування органічної продукції.

Згідно зі статтею 4 Закону України «Про основні принципи та вимоги до органічного виробництва, обігу та маркування органічної продукції», оператори органічного виробництва зобов'язані щороку проходити сертифікацію своєї діяльності для підтвердження відповідності вимогам законодавства у сфері органічного виробництва, обігу та маркування органічної продукції. Із цією метою виробники органічної продукції повинні взаємодіяти 3 органами сертифікації та забезпечувати безперешкодний доступ інспекторів із органічного виробництва до своїх потужностей та відбору зразків, а також надавати на вимогу органів сертифікації документи, необхідні для сертифікації органічного виробництва, доступ до фінансових документів [14]. Відповідно, органи сертифікації мають право вимагати від оператора документи, що підтверджують дотримання норм законодавства щодо органічного виробництва. Такими доказами є первинні документи з відображення витрат органічного виробництва.

Реалізація інформаційної функції забезпечується включенням до змістовної частини документу всієї необхідної інформації із виділенням ії ознак за напрямами подальшого використання. Виділення ознак інформації за напрямами використання дає можливість здійснювати групування інформації для різних рівнів управління, у різних розрізах для формування звітних $\mathrm{i}$ аналітичних форм.

Враховуючи вимоги до ведення органічного виробництва (рис. 3), при формуванні пакету первинних документів, особливу увагу варто звернути на документування витрат виробничих ресурсів.

Зазначені вимоги та заборони обумовлюють необхідність створення спеціалізованих форм первинного обліку витрат на придбання і використання насіння, посадкового матеріалу, засобів захисту рослин і тварин, добрив для забезпечення ефективного контролю за процесом виробництва органічної продукції. Водночас, слід врахувати організаційно-технологічні особливості та специфіку контролю під час перехідного періоду, в умовах «чистого» органічного виробництва та паралельного виробництва органічної i неорганічної продукції. 


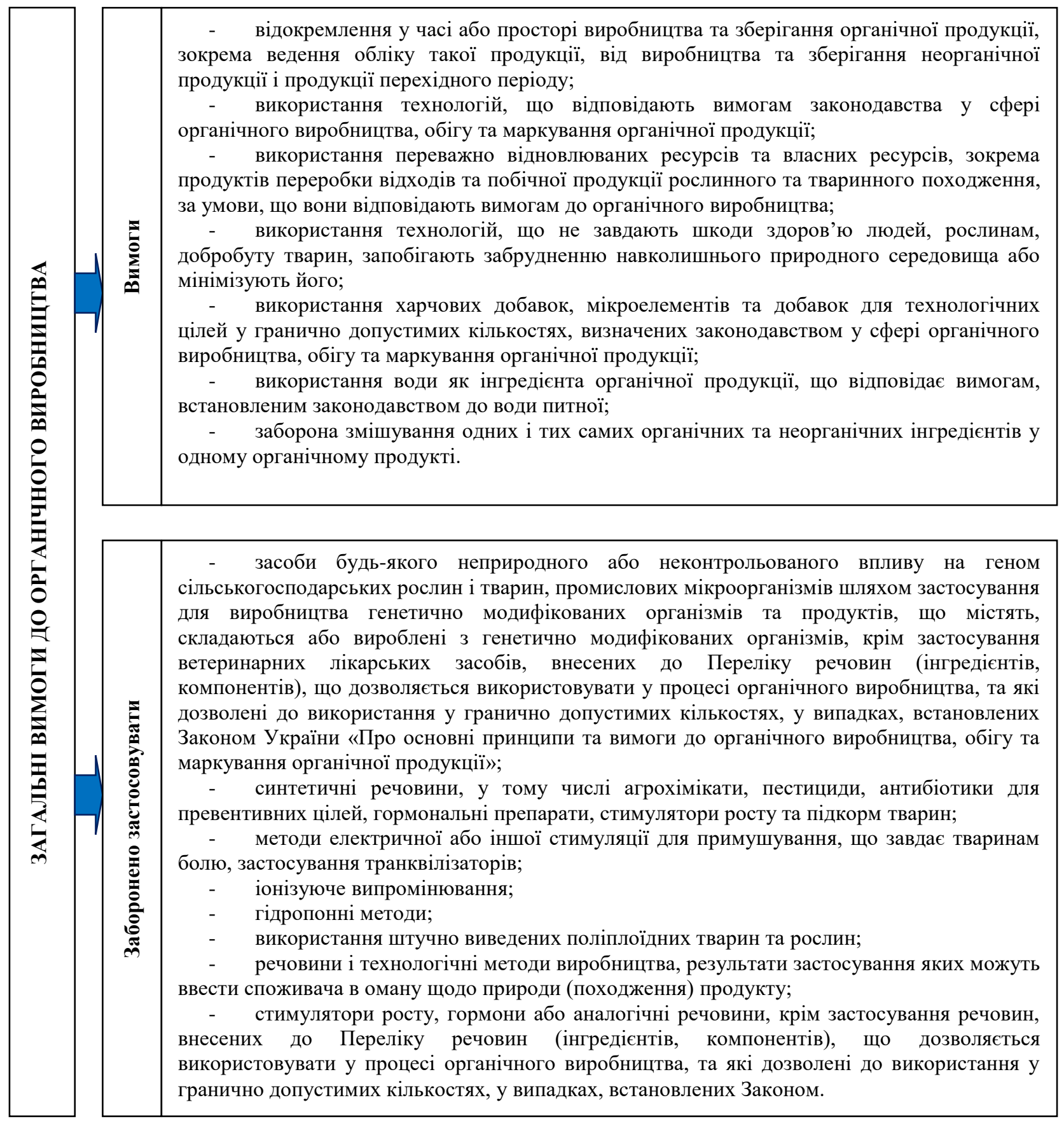

\section{Рис. 3. Загальні вимоги до органічного виробництва в Україні}

Джерело: сформовано авторами на основі [14]

В умовах як традиційного ведення сільськогосподарського виробництва, так і органічного виробництва, суб'єкти господарювання використовують спеціалізовані, а також деякі типові форми документів для документування операцій із надходження, зберігання, переміщення та вибуття запасів. За цих обставин, надходження матеріальних цінностей від постачальників оформляється рахунками-фактурами, платіжними вимогами з специфікацією, товарно-транспортними накладними на загальних підставах. Ці документи слід реєструвати у формі № М-1 «Журнал обліку вантажів, що надійшли».

Під час перехідного періоду та в умовах паралельного виробництва 


\section{EФM \\ http://efm.vsau.org/}

органічної і неорганічної продукції, підприємствам необхідно організувати відокремлене зберігання запасів для кожного з видів виробництва. На вхідних супровідних документах слід здійснювати помітки, наприклад, «органічний склад» та «неорганічний склад».

У разі ведення паралельного виробництва оператор зобов'язаний надавати органу сертифікації документальне підтвердження дотримання положень статті 26 Закону № 2496-VIII та забезпечувати:

- вжиття належних заходів для постійного розділення органічної i неорганічної продукції, органічних і неорганічних тварин;

- розділення органічного та неорганічного гною, органічних i неорганічних кормів;

- належне очищення виробничого обладнання для здійснення технологічних операції із органічною продукцією;

- подання до органу сертифікації інформації про кількість виробленої органічної та неорганічної продукції;

- подання до органу сертифікації інформації про збирання врожаю не пізніше, ніж за два робочі дні до початку збору врожаю;

- подання до органу сертифікації інформації про будь-яке переміщення або продаж тварин, продуктів тваринництва;

- подання інформації до органу сертифікації про зібраний врожай, вирощених тварин і продукцію тваринництва та вжиті заходи для розділення органічної і неорганічної продукції [14].

Для забезпечення документального підтвердження зазначених заходів, до типових та спеціалізованих форм первинних документів для сільського господарства необхідно ввести додаткові реквізити. Доцільно сформувати додаткові форми документів, які необхідні для підтвердження дотримання норм законодавства, проте, відсутні в переліку уже розроблених форм.

Разовий відпуск матеріалів, кормів, насіння, добрив, засобів захисту рослин та тварин, сировини, запасних частин та інших товарно-матеріальних цінностей для використання або переміщення у господарстві здійснюють за накладними (внутрішньогосподарського призначення) (форма ВЗСГ-8). Накладну, як правило, виписують у двох примірниках, один із яких передають на склад, а другий - одержувачу цінностей.

При систематичному відпуску матеріалів, замість разових накладних, використовують нагромаджувальний документ - лімітно-забірну карту на одержання матеріальних цінностей (форма ВЗСГ-1, ВЗСГ-2).

Після внесення мінеральних, органічних і бактеріальних добрив та засобів хімічного захисту рослин у кожне поле в розрізі культур оформляють Акт про використання мінеральних, органічних i бактеріальних добрив, отрутохімікатів та гербіцидів (форма ВЗСГ-3).

Для контролю за дотриманням вимог органічного виробництва, у зазначені первинні документи варто ввести реквізити, які дають змогу ідентифікувати використані матеріальні цінності, як дозволені, або дозволені в 


\section{EФМ}

http://efm.vsau.org/

гранично допустимих кількостях. Для цього доцільно у додаткових графах зазначати розділ та номер використаних речовин, інгредієнтів, компонентів згідно з Переліком речовин (інгредієнтів, компонентів), що дозволяється використовувати у процесі органічного виробництва, та які дозволені до використання у гранично допустимих кількостях № 1073 від 09.06.2020 р. (далі Перелік) [15]. Для прикладу наведемо пропоновану форму Акту про використання речовин (інгредієнтів, компонентів), що дозволяється використовувати у процесі органічного виробництва, та які дозволені до використання у гранично допустимих кількостях (рис. 4).

ЗАТВЕРДЖУЮ

\begin{tabular}{lr}
\hline ПІП \\
“_ підпис керівника \\
\hline
\end{tabular}

Сільськогосподарське підприємство

Ідентифікаційний код СДРПОУ

Структурний підрозділ

АКТ №

про використання речовин (інгредієнтів, компонентів), що дозволяється використовувати у процесі органічного виробництва та які дозволені до використання у гранично допустимих кількостях

за $20 \_$p.

Призначення і спосіб застосування речовин (інгредієнтів, компонентів) основне, передпосівне тощо

підживлення, суцільний, місцевий і т. д.

Внесено на землях

сертифікованих під органічне виробництво, перехідного періоду

\begin{tabular}{|c|c|c|c|c|c|c|c|c|c|}
\hline \multirow[b]{2}{*}{$\begin{array}{l}\text { Назва речовин } \\
\text { (інгредієнтів, } \\
\text { компонентів) }\end{array}$} & \multirow{2}{*}{ 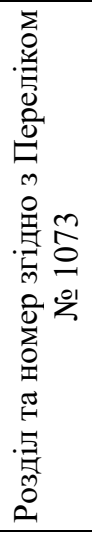 } & \multicolumn{2}{|c|}{$\begin{array}{c}\text { Код синтетичного } \\
\text { обліку }\end{array}$} & \multirow[b]{2}{*}{ 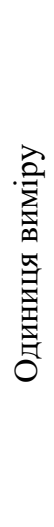 } & \multirow[b]{2}{*}{ 茎 } & \multicolumn{4}{|c|}{ Номер поля, назва культури } \\
\hline & & дебет & кредит & & & 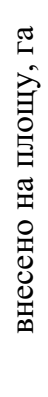 & 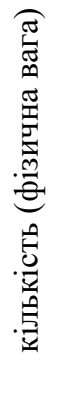 & 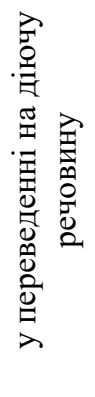 & сума \\
\hline & & & & & & & & & \\
\hline
\end{tabular}

Рис. 4. Пропонована форма Акту про використання речовин (інгредіснтів, компонентів) у процесі органічного сільськогосподарського виробництва

Джерело: власна розробка авторів

В органічному рослинництві вимагається використовувати для сівби органічне насіння та органічний садивний матеріал. Із метою отримання органічного насіння і садивного матеріалу, материнська рослина та інші 


\section{EФM \\ http://efm.vsau.org/}

рослини повинні бути розмножені, відповідно до вимог органічного законодавства, протягом щонайменше одного покоління, а для багаторічних культур - протягом щонайменше одного покоління та двох вегетаційних періодів [16].

Для списання насіння і садивного матеріалу до витрат на вирощування відповідних сільськогосподарських культур, використовується спеціалізована форма «Акт витрати насіння і садивного матеріалу» (форма № ВЗСГ-4). У зазначеному документі, в умовах органічного виробництва, крім стандартних реквізитів, варто зазначати додаткову інформацію:

- на яких землях проведено посів (сертифікованих під органічне виробництво, перехідного періоду);

- специфікацію придбаного посівного матеріалу як такого, що вирощений в умовах органічного виробництва;

- розділ та номер використаних речовин, інгредієнтів, компонентів, згідно 3 Переліком № 1073, що були використані для оброблення насіння від хвороб та шкідників.

Оператори органічного виробництва зобов'язані забезпечити відокремлене зберігання та особливі умови транспортування органічної продукції. Для цього слід організувати відокремлене складське господарство та відокремлений складський облік органічної рослинницької продукції, отриманої із виробництва. Такі вимоги визначені в Законі України «Про основні принципи та вимоги до органічного виробництва, обігу та маркування органічної продукції» [14]. Зокрема, Закон вимагає, під час зберігання незапакованої продукції рослинництва, забезпечити облік та ідентифікацію такої продукції і кожної іiї партії як органічної та унеможливити іiї змішування 3 неорганічною продукцією, зокрема продукцією перехідного періоду, а також із забруднюючими речовинами.

Безпосередньо перед відправкою продукції відбираються проби для іiі лабораторних аналізів. Після підтвердження якості продукції іiї запаковують та пломбують.

Перевезення незапакованої органічної продукції повинно здійснюватися лише в опломбованій упаковці, контейнері або транспортних засобах, закритих так, щоб унеможливити відкриття без пошкодження пломби. Опломбування упаковки, контейнера або транспортного засобу здійснюється оператором [16].

На практиці всі процедури, пов'язані з відбором зразків для лабораторних аналізів, пакування, затарювання, пломбування, фотографуються для забезпечення додаткових доказів дотримання законодавства у сфері органічного виробництва.

У товарно-транспортній накладній на відправку органічної продукції повинна надаватись додаткова інформація, що не передбачена у типових та спеціалізованих формах цього документу. Зокрема, це інформація щодо:

- назви органічної продукції та ії опису;

- назви та реєстраційного коду органу сертифікації, який здійснив 


\section{EФМ}

http://efm.vsau.org/

сертифікацію органічного виробництва; продукції.

- переліку документів, що додаються, і які підтверджують якість

Висновки. Зважаючи на особливості організації бізнес-процесів органічного виробництва, виокремлено функції первинних документів в управлінні виробництвом органічної продукції. Розроблено пропозиції щодо документування витрат насіння, посадкового матеріалу, засобів захисту рослин, добрив для забезпечення ефективного контролю за процесом виробництва органічної продукції. Водночас, враховуються організаційно-технологічні особливості та специфіка контролю під час перехідного періоду, в умовах «чистого» органічного виробництва та паралельного виробництва органічної $\mathrm{i}$ неорганічної продукції. Зокрема, запропоновано форму Акту про використання речовин (інгредієнтів, компонентів), що дозволяється використовувати у процесі органічного виробництва, та які дозволені до використання у гранично допустимих кількостях.

У статті ми розробили пропозиції щодо документального оформлення витрат органічного рослинництва. Перспективними напрямками подальших наукових досліджень із даної проблематики $\epsilon$ розробка пакету первинних документів для інших галузей органічного виробництва та формування методичних рекомендацій щодо документування всіх його бізнес-процесів, що стане основою формування інформаційної системи управління органічним виробництвом на всіх його рівнях, забезпечить можливість оцінки стану органічного виробництва та формування стратегії його розвитку.

\section{Список використаних джерел}

1. Національна економічна стратегія на період до 2030 року: Постанова Кабінету Міністрів України від 3 березня 2021 р. № 179. URL: https://www.kmu.gov.ua/npas/pro-zatverdzhennya-nacionalnoyi-eko-a179 (дата звернення 03.04.2021).

2. Калетнік Г.М., Пришляк Н.В. Виробництво та сертифікація органічної продукції: досвід США. Економіка, фінанси, менеджмент: актуальні питання науки і практики. 2017. № 9 (25). С. 7-22.

3. Гончарук I.В., Томашук I.В. Вплив еколого-економічного фактору на особливості організаційно-економічного механізму використання ресурсного потенціалу сільських територій. Економіка, фінанси, менеджмент: актуальні питання науки і практики. 2017. № 4 (20). С. 52-62.

4. Ковальчук С.Я. Органічне виробництво в системі сталого розвитку сільських територій. Економіка, фінанси, менеджмент: актуальні питання науки і практики. 2020. № 4 (54). C. 117-133. DOI: 10.37128/2411-4413-2020-4-8.

5. Подолянчук О.А. Сутність та основи обліку органічної продукції. Агросвіт. 2019. № 16. С. 51-57. DOI: 10.32702/2306-6792.2019.16.51.

6. Маркевич Л.С., Подолянчук О.А. Понятійний апарат «органічна продукція» та напрями іiї обліку. Агросвіт. 2020. № 4. С. 99-104. 
DOI: $10.32702 / 2306-6792.2020 .4 .99$.

7. Цаль-Цалко Ю.С. Статистичний і бухгалтерський облік органічного виробництва. Наукові горизонти. 2018. № 5 (68). С. 70-77.

8. Кириленко І.Г., Милованов С.В. Наукове забезпечення розвитку органічного агровиробництва. Економіка АПК. 2019. № 3. С. 27-41. DOI: https://doi.org/10.32317/2221-1055.201903027.

9. Іщенко Я.П. Облік витрат та виходу органічної сільськогосподарської продукції рослинництва. Інститут бухгалтерського обліку, контроль та аналіз в умовах глобалізації. 2019. № 3-4. С.26-36. DOI: https://doi.org/10.35774/ibo2019.03.026.

10. Іщенко Я.П. Особливості організації обліку витрат органічного сільськогосподарського виробництва. Економіка, фінанси, менеджмент: актуальні питання науки $і$ практики. 2019. № 7 (47). С. 122-132. DOI: $10.37128 / 2411-4413-2019-7-14$.

11. Органік в Україні. URL: http://organic.com.ua/organic-v-ukraini/ (дата звернення: 14.04.2021).

12. Положення про документальне забезпечення записів у бухгалтерському обліку: Наказ Міністерства фінансів України від 24.05.1995 № 88. URL: https://zakon.rada.gov.ua/laws/show/z0168-95\#Text (дата звернення: 20.04.2021)

13. Гудзенко Н.М., Коваль Н.І., Плахтій Т.Ф. Вплив інформаційних потреб користувачів на структуру та поповнення фінансової звітності. Економіка, фінанси, менеджмент: актуальні питання науки і практики. 2018. № 5 (33). С. 102-113.

14. Про основні принципи та вимоги до органічного виробництва, обігу та маркування органічної продукції: Закон України від 10.07.2018 р. № 2496VIII. URL: https://zakon.rada.gov.ua/laws/show/2496-19 (дата звернення: 22.04.2021).

15. Перелік речовин (інгредієнтів, компонентів), що дозволяється використовувати у процесі органічного виробництва та які дозволені до використання у гранично допустимих кількостях: Наказ Міністерства розвитку економіки, торгівлі та сільського господарства України від 09.06.2020p. № 1073. URL: https://zakon.rada.gov.ua/laws/show/z0763-20\#Text (дата звернення: 22.04.2021).

16. Порядок (детальні правила) органічного виробництва та обігу органічної продукції: Постанова Кабінету Міністрів України від 23.10.2019 р. № 970. URL: https://zakon.rada.gov.ua/laws/show/970-2019-\%D0\%BF\#Text (дата звернення: 22.04.2021).

\section{References}

1. Natsionalna ekonomichna stratehiia na period do 2030 roku: Postanova Kabinetu Ministriv Ukrainy vid 3 bereznia 2021 r. № 179 [National Economic 


\section{EФM \\ http://efm.vsau.org/}

Strategy for the period up to 2030: Resolution of the Cabinet of Ministers of Ukraine of March 3, 2021 № 179]. kmu.gov.ua. Retrieved from: https://www.kmu.gov.ua/npas/pro-zatverdzhennya-nacionalnoyi-eko-a179 [in Ukrainian].

2. Kaletnik, G.M., \& Pryshliak, N.V. (2017). Vyrobnytstvo ta sertyfikatsiia orhanichnoi produktsii: dosvid SShA [Production and Certification of Organic Products: US Experience]. Ekonomika, finansy, menedzhment: aktualni pytannia nauky i praktyky - Economy, finances, management: topical issues of science and practic activity, 9 (25), 7-22 [in Ukrainian].

3. Honcharuk, I.V., \& Tomashuk, I.V. (2017). Vplyv ekolohoekonomichnoho faktoru na osoblyvosti orhanizatsiino-ekonomichnoho mekhanizmu vykorystannia resursnoho potentsialu silskykh terytorii [Influence of the ecological and economic factor on the peculiarities of the organizational and economic mechanism of using the resource potential of rural territories]. Ekonomika, finansy, menedzhment: aktualni pytannia nauky i praktyky - Economy, finances, management: topical issues of science and practic activity, 4 (20), 52-62 [in Ukrainian].

4. Kovalchuk, S.Ya. (2020). Orhanichne vyrobnytstvo v systemi staloho rozvytku silskykh terytorii [Organic production in the system of sustainable development of rural areas]. Ekonomika, finansy, menedzhment: aktualni pytannia nauky i praktyky - Economics, finance, management: current issues of science and practic activity, 4 (54), 117-133. DOI: 10.37128/2411-4413-2020-4-8 [in Ukrainian].

5. Podolianchuk, O.A. (2019). Sutnist ta osnovy obliku orhanichnoi produktsii [The essence and basics of accounting for organic products]. Ahrosvit Agrosvit, 16, 51-57. DOI: 10.32702/2306-6792.2019.16.51 [in Ukrainian].

6. Markevych, L.S., \& Podolianchuk, O.A. (2020). Poniatiinyi aparat «orhanichna produktsiia» ta napriamy yii obliku [The conceptual apparatus of «organic products» and areas of its accounting]. Ahrosvit - Agroworld, 4, 99-104. DOI: 10.32702/2306-6792.2020.4.99 [in Ukrainian].

7. Tsal-Tsalko, Yu.S. (2018). Statystychnyi i bukhhalterskyi oblik orhanichnoho vyrobnytstva [Statistical and accounting of organic production]. Naukovi horyzonty - Scientific horizons, 5, 70-77 [in Ukrainian].

8. Kyrylenko, I.H., \& Mylovanov, Ye.V. (2019). Naukove zabezpechennia rozvytku orhanichnoho ahrovyrobnytstva [Scientific support for the development of organic agriculture]. Ekonomika APK - Economics of agro-industrial complex, 3, 2741. DOI: https://doi.org/10.32317/2221-1055.201903027 [in Ukrainian].

9. Ishchenko, Ya.P. (2019). Oblik vytrat ta vykhodu orhanichnoi silskohospodarskoi produktsii roslynnytstva [Accounting for costs and yield of organic agricultural crop products]. Instytut bukhhalterskoho obliku, kontrol ta analiz v umovakh hlobalizatsii - Institute of Accounting, Control and Analysis in the Context of Globalization, 3-4, 26-36 [in Ukrainian].

10. Ishchenko, Ya.P. (2019). Osoblyvosti orhanizatsii obliku vytrat 
orhanichnoho silskohospodarskoho vyrobnytstva [Features of the organization of the account of expenses of organic agricultural production]. Ekonomika, finansy, menedzhment: aktualni pytannia nauky i praktyky - Economy, finances, management: topical issues of science and practic activity, 7 (47), 122-132 [in Ukrainian].

11. Orhanik v Ukraini [Organic in Ukraine]. organic.com.ua. Retrieved from: http http://organic.com.ua/organic-v-ukraini/ [in Ukrainian].

12. Polozhennia pro dokumentalne zabezpechennia zapysiv $u$ bukhhalterskomu obliku: Nakaz Ministerstva finansiv Ukrainy vid 24.05.1995 № 88 [Regulations on documentary support of records in accounting: Order of the Ministry of Finance of Ukraine dated 24.05.1995 № 88]. zakon.rada.gov.ua. Retrieved from: https://zakon.rada.gov.ua/laws/show/z0168-95\#Text [in Ukrainian].

13. Hudzenko, N.M., Koval, N.I., \& Plakhtii, T.F. (2018). Vplyv informatsiinykh potreb korystuvachiv na strukturu ta popovnennia finansovoi zvitnosti [Influence of information needs of users on the structure and replenishment of financial statements]. Ekonomika, finansy, menedzhment: aktualni pytannia nauky $i$ praktyky - Economy, finances, management: topical issues of science and practic activity, 5 (33), 102-113 [in Ukrainian].

14. Zakon Ukrainy «Pro osnovni pryntsypy ta vymohy do orhanichnoho vyrobnytstva, obihu ta markuvannia orhanichnoi produktsii» vid 10.07.2018 roku № 2496-VIII [Law of Ukraine «On Basic Principles and Requirements for Organic Production, Turnover and Marking of Organic Products» № 2496-VIII]. (2018, July 10). Retrieved from: https://zakon.rada.gov.ua/laws/show/2496-19 [in Ukrainian].

15. Perelik rechovyn (inhrediientiv, komponentiv), shcho dozvoliaietsia vykorystovuvaty $\mathrm{u}$ protsesi orhanichnoho vyrobnytstva ta yaki dozvoleni do vykorystannia u hranychno dopustymykh kilkostiakh: Nakaz Ministerstva rozvytku ekonomiky, torhivli ta silskoho hospodarstva Ukrainy vid 09.06.2020 r. № 1073 [List of substances (ingredients, components) that are allowed to be used in the process of organic production and which are allowed to be used in the maximum permissible quantities: Order of the Ministry of Economic Development, Trade and Agriculture of Ukraine № 1073]. (2020, June 9). zakon.rada.gov.ua. Retrieved from: https://zakon.rada.gov.ua/laws/show/z0763-20\#Text [in Ukrainian].

16. Poriadok (detalni pravyla) orhanichnoho vyrobnytstva ta obihu orhanichnoi produktsii: Postanova kabinetu Ministriv Ukrainy vid 23.10.2019 r. № 970 [Procedure (detailed rules) of organic production and circulation of organic products: Resolution of the Cabinet of Ministers № 970]. (2019, October 23). zakon.rada.gov.ua. Retrieved from: https://zakon.rada.gov.ua/laws/show/970-2019-\%D0\%BF\#Text [in Ukrainian].

\section{Інформація про авторів}

ІЩЕНКО Яна Петрівна - кандидат економічних наук, доцент кафедри обліку та оподаткування в галузях економіки, Вінницький національний 


\section{EФМ}

http://efm.vsau.org/

аграрний університет (21008, м. Вінниця, вул. Сонячна, 3, e-mail: jana_2006@ukr.net).

КОВАЛЬ Наталія Іванівна - кандидат економічних наук, доцент кафедри обліку та оподаткування в галузях економіки, Вінницький національний аграрний університет (21008, м. Вінниця, вул. Сонячна, 3, e-mail: Natkov@i.ua).

ISHCHENKO Yana - Candidate of Economic Sciences, Associate Professor of the Department of Accountand Taxationin the Fields of the Economy, Vinnytsia National Agrarian University (21008, Vinnytsia, 3, Soniachna Str., e-mail: jana_2006@ukr.net).

KOVAL Natalia - Candidate of Economic Sciences, Associate Professor of the Department of Account and Taxationin the Fields of the Economy, Vinnytsia National Agrarian University (21008, Vinnytsia, 3, Soniachna Str., e-mail: Natkov@i.ua).

ИЩЕНКО Яна Петровна - кандидат экономических наук, доцент кафедры учета и налогообложения в отраслях экономики, Винницкий национальный аграрный университет $(21008$, г. Винница, ул. Солнечная, 3, e-mail: jana_2006@ukr.net).

КОВАЛЬ Наталия Ивановна - кандидат экономических наук, доцент кафедры учета и налогообложения в отраслях экономики, Винницкий национальный аграрный университет $(21008$, г. Винница, ул. Солнечна, 3, e-mail: Natkov@i.ua).

УДК 343.98

DOI: $10.37128 / 2411-4413-2021-3-9$

ТЕОРЕТИКО-

ПРАВОВІ АСПЕКТИ

ЗАСТОСУВАННЯ

ФIНАНСОВИХ

ГАРАНТІЙ ЗА

ТРАНЗИТНИМИ

ЗОВНІШНЬО-

ЕКОНОМІЧНИМИ

ОПЕРАЦІЯМИ
ХОМУТЕНКО В.П., кандидат економічних наук, професор, незалежний судовий експерт

ХОМУТЕНКО А.В., доктор економічних наук, професор, професор кафедри фінансів, Одеський національний економічний університет (м. Odeca)

У статті обтрунтовано необхідність застосування способів забезпечення сплати митних платежів, серед яких фінансові гарантії. Доведено, щзо фінансові гарантії $\epsilon$ методом забезпечення виконання митних зобов'язань при порушенні умов надання звільнення від оподаткування, в тому числі й у митному режимі «транзит». Проаналізовано обсяги транзиту через митну територію України з краӥн СС за 2014-2020 рр. Визначено сутність та ознаки транзитних зовнішньоекономічних операцій. Охарактеризовано випадки, за яких транзит буде вважатися перерваним транзитом (прихованим імпортом). Наведено статистичні дані, які свідчать, щуо значна частка транзитних операчій визнається митними органами Украӥни перерваним транзитом. Досліджено обсяги наданих фінансових 